\title{
Pathogen Profile
}

\section{Current understanding on Villosiclava virens, a unique flower-infecting fungus causing rice false smut disease}

\author{
JING FAN ${ }^{1}$, JUAN YANG ${ }^{1}, Y U-Q I U$ WANG $^{1}$, GUO-BANG LI ${ }^{1}$, YAN LI $^{1}$, FU HUANG $^{1,2}$ \\ AND WEN-MING WANG ${ }^{1}$, * \\ ${ }^{1}$ Rice Research Institute \& Key Laboratory for Major Crop Diseases, Sichuan Agricultural University, Chengdu 611130, China \\ ${ }^{2}$ College of Agronomy \& Institute of Agricultural Ecology, Sichuan Agricultural University, Chengdu 611130, China
}

\section{SUMMARY}

Villosiclava virens $(\mathrm{VV})$ is an ascomycete fungal pathogen that causes false smut disease in rice. Recent reports have revealed some interesting aspects of the enigmatic pathogen to address the question of why it specifically infects rice flowers and converts a grain into a false smut ball. Comparative and functional genomics have suggested specific adaptation of $\mathrm{V} v$ in the colonization of rice flowers. Anatomical studies have disclosed that $\mathrm{Vv}$ specifically infects rice stamen filaments before heading and intercepts seed formation. In addition, $\mathrm{Vv}$ can occupy the whole inner space of a spikelet embracing all floral organs and activate the rice grain-filling network, presumably for nutrient acquisition to support the development of the false smut ball. This profile provides a general overview of the rice false smut pathogen, and summarizes advances in the Vv life cycle, genomics and genetics, and the molecular Vv-rice interaction. Current understandings of the Vv-rice pathosystem indicate that it is a unique and interesting system which can enrich the study of plant-pathogen interactions.

Taxonomy: Ustilaginoidea virens is the anamorph form of the pathogen (Kingdom Fungi; Phylum Ascomycota; Class Ascomycetes; Subclass Incertae sedis; Order Incertae sedis; Family Incertae sedis; Genus Ustilaginoidea). The teleomorph form is Villosiclava virens (Kingdom Fungi; Phylum Ascomycota; Class Ascomycetes; Subclass Sordariomycetes; Order Hypocreales; Family Clavicipitaceae; Genus Villosiclava).

Disease symptoms: The only visible symptom is the replacement of rice grains by ball-shaped fungal mycelia, namely false smut balls. When maturing, the false smut ball is covered with powdery chlamydospores, and the colour changes to yellowish, yellowish orange, green, olive green and, finally, to greenish black. Sclerotia are often formed on the false smut balls in autumn.

Identification and detection: $\mathrm{Vv}$ conidia are round to elliptical, measuring 3-5 $\mu \mathrm{m}$ in diameter. Chlamydospores are ornamented with prominent irregularly curved spines, which are $200-500 \mathrm{~nm}$ in length. The sclerotia are black, horseshoe-shaped and irregular oblong or flat, ranging from 2 to $20 \mathrm{~mm}$. Nested polymerase

\footnotetext{
*Correspondence: Email: j316wenmingwang@sicau.edu.cn
}

chain reaction (PCR) and quantitative PCR have been developed to specifically detect $\mathrm{V} v$ presence in rice tissues and other biotic and abiotic samples in fields.

Host range: Rice is the primary host for Vv. Natural infection by Vv has been found on several paddy field weeds, including Digitaria marginata, Panicum trypheron, Echinochloa crusgalli and Imperata cylindrica. However, the occurrence of infection in these potential alternative hosts is very rare.

Life cycle: $V v$ infects rice spikelets at the late rice booting stage, and produces false smut balls covered with dark-green chlamydospores. Occasionally, sclerotia form on the surface of false smut balls in late autumn when the temperature fluctuates greatly between day and night. Both chlamydospores and sclerotia may serve as primary infection sources. Rainfall at the rice booting stage is a major environmental factor resulting in epidemics of rice false smut disease.

Disease control: The use of fungicides is the major approach for the control of Vv. Several fungicides, such as cuproxat SC, copper oxychloride, tebuconazole, propiconazole, difenoconazole and validamycin, are often applied. However, the employment of resistant rice cultivars and genes has been limited, because of the poor understanding of rice resistance to $\mathrm{V} v$.

Useful websites: Villosiclava virens genome sequence: http:// www.ncbi.nlm.nih.gov/Traces/wgs/?val= JHTR01\#contigs

Keywords: biotroph, effector, epiphytic growth, flowerinfecting, grain-filling, rice false smut ball, Ustilaginoidea virens.

\section{INTRODUCTION}

Villosiclava virens (Vv) is an ascomycete fungus, which possesses a teleomorphic state producing sexual ascospores and an anamorphic state generating asexual chlamydospores. The anamorph and teleomorph forms of the fungus have been given the names Ustilaginoidea virens (Cooke) Takahashi and Villosiclava virens, respectively (Tanaka et al., 2008). Both sexual and asexual spores can infect the rice spikelet and convert a rice grain into a ball of mycelium (Ikegami, 1960, 1963a; Wang, 1995; Yoshino and Yamamoto, 1952). 

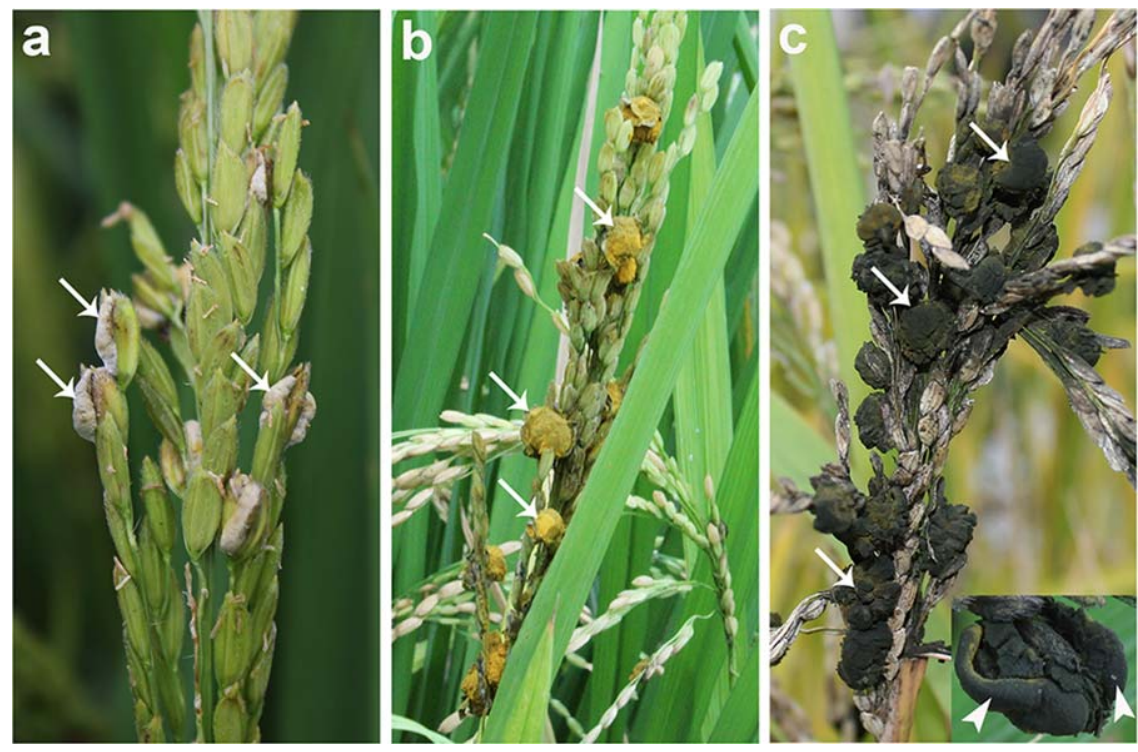

Fig. 1 Typical symptoms of rice false smut disease caused by Villosiclava virens (Vv). False smut balls are formed in $\mathrm{V}$-infected rice panicles. During disease progression, the colour of false smut balls changes from white (a) to yellowish (b) and, ultimately, to greenish black (c). Sclerotia (inset) are usually formed on false smut balls in autumn. Arrows and arrowheads indicate false smut balls and sclerotia, respectively.

$\mathrm{Vv}$ is not a bona fide smut fungus and Vv-caused disease is called false smut disease (Bischoff et al., 2004). This disease not only reduces rice yield and grain quality (Chib et al., 1992; Jiang et al., 2009; Ono and Uehara, 1949; Osada, 1995; Yang et al., 2012), but also leads to the contamination of grains and straws with $\mathrm{V} v$ produced mycotoxins, which are poisonous to both humans and animals (Koiso et al., 1994; Nakamura et al., 1994; Zhou et al., 2012). Thus, food safety requires a rapid and accurate detection of $\mathrm{V} v$ mycotoxins (Fu et al., 2015a,b; Ji et al., 2012; Miyazaki et al., 2009; Shan et al., 2012, 2013, 2014). In recent years, rice false smut disease has been increasingly recorded in rice-growing areas worldwide (Brooks et al., 2010; Guo et al., 2012; Jecmen and TeBeest, 2015; Ladhalakshmi et al., 2012; Singh and Pophaly, 2010), and has attracted increasing attention from researchers and farmers.

Despite several efforts on field screening for resistant rice cultivars and quantitative resistance locus (QRL) analysis (Guo et al., 2012; Huang et al., 2015; Zhou et al., 2014), rice resistance genes against $\mathrm{V} v$ have not been identified. The inheritance of false smut resistance is still obscure, hindering breeding for resistance to false smut pathogen. The development of efficient strategies to control rice false smut disease requires a detailed understanding of the biology, genetics and pathogenicity of the pathogen. This profile provides an overview of the current knowledge on $V_{V}$, focusing on updates in the $V v$ life cycle, genomics and genetics, and its molecular interaction with rice.

\section{DISEASE SYMPTOMS AND CONTROL}

The typical symptom caused by $V v$ in rice is the formation of a white fungal mass protruding from the inner space of a spikelet at the early infection stage, followed by transformation into a light-yellow smut ball which, ultimately, changes colour to greenish-black (Fig. 1). The outer layer of the mature smut ball consists of numerous chlamydospores, and is often covered by sclerotia in autumn (Fig. 1c) (Ikegami, 1961, 1963a). False smut ball is the only disease symptom identified so far. In a rice panicle, only some of the spikelets are randomly infected and converted into false smut balls (Fig. 1).

Currently, the control of rice false smut disease mostly relies on fungicides. Several fungicides, such as Wenquning (a suspension of Bacillus subtilis in a solution of validamycin), copper hydroxide, copper oxychloride, cuproxat SC, simeconazole, horizon, tebuconazole, difenoconazole and hexaconazole, have been shown to possess over $70 \%$ control against rice false smut disease (Ahonsi and Adeoti, 2003; Gao et al., 2010; Liang et al., 2014; Tripathi et al., 2014; Tsuda et al., 2006; Zhou and Wang, 2011). It should be noted that the timing of spraying with fungicides is critical for control. For instance, the fungicide simeconazole is found to be more effective against rice false smut disease when applied 3 weeks before rice heading (Tsuda et al., 2006).

Alternatively, cultural management has been investigated in the control of rice false smut disease. Brooks et al. (2009) reported that conservation tillage, continuous rice cropping and moderate nitrogen fertility rates could lead to $69 \%, 88 \%$ and $34 \%$, reduction, respectively, in rice false smut disease for susceptible cultivars in Arkansas, USA. Furrow irrigation has also been shown to greatly suppress rice false smut disease in susceptible rice varieties (Brooks et al., 2010). However, furrow irrigation is not practicable in all rice fields and may result in severe rice blast disease in some varieties (Bonman, 1992).

\section{IDENTIFICATION AND DETECTION}

The rice false smut ball is covered with chlamydospores, which are round to elliptical and measure from 3 to $5 \mu \mathrm{m}$ in diameter 
(Kim and Park, 2007). Irregularly curved spines with a length of 200-500 nm can be observed on the surface of chlamydospores (Kim and Park, 2007). The mature false smut ball sometimes produces sclerotia, which are black, horseshoe-shaped and irregular oblong or flat, and measure from 2 to $20 \mathrm{~mm}$ in length (Fig. 1c) (Fu et al., 2012). Under scanning electron microscopy, the outer sclerotial wall is rough and the interior of sclerotia is intertwined with compact hyphae (Fu et al., 2012).

At the molecular level, a polymerase chain reaction (PCR)based technique has been developed for the detection of the $\mathrm{V} v$ pathogen. Vv-specific primers and corresponding nested primers have been designed based on the rDNA internal transcribed spacers (ITS1 and ITS2) and the 5.8S rRNA gene (Zhou et al., 2003), and successfully applied for the detection of $\mathrm{V} v$ in various tissues of rice and related grasses, facilitating the early prediction of false smut disease in fields (Zhou et al., 2006). Nested PCR has also been developed to detect $\mathrm{V} v$ in rice panicles before and after heading; the results indicate the existence of the pathogen before heading (Ashizawa and Kataoka, 2005). Real-time PCR assays with higher sensitivity than the conventional nested PCR have also been set up and successfully applied to detect the existence of $\mathrm{Vv}$ in soil (Ashizawa et al., 2010), rice samples (Li H. et al., 2013) or air samples around susceptible rice plants in fields (Zheng et al., 2012).

\section{LIFE CYCLE}

Vv ascospores and chlamydospores can infect rice spikelets (Ikegami, 1960, 1963a; Wang, 1995; Yoshino and Yamamoto, 1952). Successful infection of Vv produces white ball-shaped mycelium, which ultimately develops into a false smut ball covered with dark-green chlamydospores (Ikegami, 1961; Tang et al., 2013; Zhang Y. et al., 2014). Sclerotia are often developed on the surface of false smut balls in late autumn when the temperature fluctuates greatly between day and night (Ikegami, 1963a). With regard to the sexual cycle, the sclerotia may overwinter in soil and germinate to produce stromata, which then form asci, releasing ascospores (Deng, 2015; Honkura and Kimura, 1988; Singh and Dubey, 1984; Zhang Y. et al., 2014). For the asexual cycle, chlamydospores on the surface of false smut balls may survive in nature and serve as an important source of inoculum between seasons (Biswas, 2001; Wang, 1988; Zhang Y. et al., 2014). However, there is an open question of how the germination of chlamydospores and sclerotia couples with the rice booting stage, and initiates infection in rice flowers to form false smut balls. Recent studies have provided important insights into this question.

\section{Status between infection seasons}

Many efforts have been made to uncover the status of $\mathrm{V} v$ from the end of a previous infection season to the start of the next (see below). Generally, Vv propagules from rice false smut balls have two destinations, i.e. in fields and on harvested rice seeds.

In fields, chlamydospores and sclerotia may overwinter in soil and germinate in appropriate conditions. Studies have demonstrated that the germination rate of chlamydospores decreases rapidly with storage time and maturity of the false smut ball (Fan et al., 2010; Wang, 1988; Wang and Bai, 1998), implicating chlamydospore dormancy. Nevertheless, high moisture and warm temperature (i.e. $26^{\circ} \mathrm{C}$ ) can break the dormancy of chlamydospores and promote their germination under laboratory conditions (Wang, 1988). Sclerotia can survive over 10 months in laboratory or field conditions, and maintain germination ability to produce ascospores under high humidity, $25^{\circ} \mathrm{C}$ and light conditions (Dong and Fu, 1989; Miao, 1994; Wang, 1995). The germination conditions required for chlamydospore and sclerotia can be met by the environmental conditions at the rice booting stage. It is indicated that chlamydospores and sclerotia may serve as inocula at the rice booting stage. Chlamydospores and ascospores both germinate to produce secondary conidia (Wang, 1988, 1995). Vv conidia are capable of blastogenesis and epiphytic colonization on the surfaces of various plant leaves (e.g. rice and paddy field weeds) and on abiotic surfaces under wet conditions, producing plenty of propagules in several days (Fig. 2a-d) (Fan et al., 2014). Therefore, the amount of inoculum should be greatly increased at the rice booting stage, especially under continuing rainy conditions. This might be the reason why epidemics of false smut disease occur when the rice booting stage coincides with rainy days. In addition, alternative hosts of Vv have been reported in the field, such as the common rice weeds Digitaria marginata (Shetty and Shetty, 1985), Panicum trypheron (Shetty and Shetty, 1987), Echinochloa crusgalli and Imperata cylindrica (Atia, 2004). However, infection occurrence in these potential alternative hosts is very rare in nature, indicating their limited roles in the Vv life cycle (Deng et al., 2015).

Harvested rice seeds from Vv-diseased fields are contaminated with false smut balls containing chlamydospores (Ditmore and TeBeest, 2005). Ditmore et al. (2006) confirmed the presence of $\mathrm{Vv}$ by $\mathrm{PCR}$ in rice plants grown from $\mathrm{Vv}$-contaminated seeds, but not in control plants. Three-week-old seedlings grown from healthy seeds in $\mathrm{Vv}$-contaminated soils were also detected as $\mathrm{VV}$ positive by PCR (TeBeest et al., 2010). Nevertheless, no false smut balls were found on panicles produced from contaminated seeds or grown in contaminated soils. Miao (1993) found that VVcontaminated rice seeds planted in sterile soil under controlled environmental conditions led to the formation of false smut balls in panicles, whereas panicles produced from $0.2 \% \mathrm{CuSO}_{4}$-treated seeds were not diseased. However, whether the pathogen forming the false smut balls is the same on contaminated seeds needs to be further clarified. Using a green fluorescence protein (GFP)tagged Vv strain should be a promising approach. 

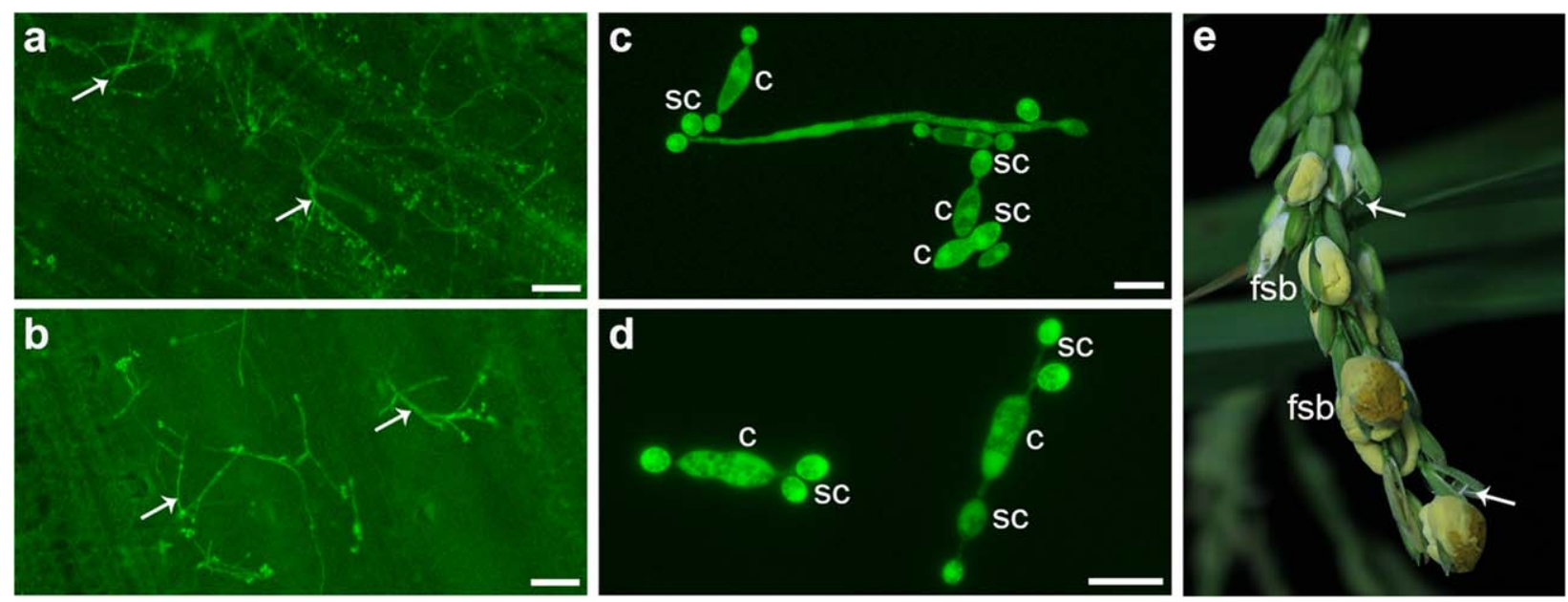

Fig. 2 Villosiclava virens (Vv) undergoes blastogenesis and epiphytic growth and can form false smut balls in a rice male-sterile mutant. (a-d) Representative epifluorescent microscopy images showing epiphytic growth and/or blastogenesis of a green fluorescent protein (GFP)-labelled Vv isolate on detached leaves of rice (a, Oryza sativa accession Pujiang 6), paddy field weed Echinochloa crusgalli (b) and abiotic surface of cellophane (c, d). White arrows indicate Vv hyphae. $c$, conidium; sc, secondary conidium. Bars, $50 \mu \mathrm{m}(\mathrm{a}, \mathrm{b}), 10 \mu \mathrm{m}(\mathrm{c}, \mathrm{d})$. (e) A representative image showing false smut balls on the rice male-sterile mutant abcg15 (Qin et al., 2013). The Vv isolate P4 was inoculated at the late booting stage and the photograph was taken at 17 days post-inoculation. White arrows indicate the white sterile anthers in abcg 15 flowers. fsb, false smut ball.

\section{Infection process in rice flowers}

It was once believed that $\mathrm{Vv}$ only infected fertilized spikelets (Chen et al., 2007). However, recently, we have found that the rice male-sterile mutant $a b c g 15$ (Qin et al., 2013) can be severely infected by Vv (Fig. 2e), indicating that rice flower fertilization is not essential for $\mathrm{V} v$ infection and the formation of a false smut ball. In addition, detailed anatomical analyses through artificial inoculation have revealed that infection occurs at the booting stage on developing spikelets before fertilization, and the ovaries in Vv-infected spikelets are interrupted in fertilization and thus are unable to set seeds (Fan et al., 2015; Tang et al., 2013). Using a Vv strain that expressed a GFP, Ashizawa et al. (2012) demonstrated the infection route of $V v$ in rice panicles after artificial inoculation. After injection into rice sheaths at the late booting stage (5-7 days before heading), Vv conidia germinate on the surface of developing spikelets, and hyphae gradually grow into the inner space of spikelets through the small gap between the lemma and palea. In this phase, Vv presumably undergoes epiphytic growth, so that no infection sites are observed on the spikelet surface. Sequentially, hyphae extend into the inner floral organs, including the anthers, filaments, stigmata and lodicules, and ultimately embrace all the organs (Ashizawa et al., 2012). More detailed histological examinations of false smut balls from both artificial inoculation and natural infection have revealed that $V v$ infects the stamen filaments and occasionally attacks the stigma and lodicules; however, no infection of the ovary could be found (Tang et al., 2013). The pathogen hyphae extend intercellularly along the filament base, and no specialized fungal infection structures, such as appressoria and haustoria, were detected
(Tang et al., 2013). By exploiting a GFP-tagged strain, Hu et al. (2014) also demonstrated that stamen filaments were the primary sites of $\mathrm{Vv}$ colonization.

\section{Life style and infection type}

It was once a topic of debate whether $\mathrm{Vv}$ is a biotroph or necrotroph and whether $V v$ is a systemic infection or flower-specific pathogen (Gao and Zhong, 2011). Progress made in recent years has indicated that $\mathrm{Vv}$ is a biotroph and flower-infecting pathogen, although it can asymptomatically colonize other rice organs and other plants (Fan et al., 2014, 2015; Tang et al., 2013; Zhang Y. et al., 2014).

Vv attacks rice floral organs and grows intercellularly without killing host cells (Tang et al., 2013). During the formation of false smut balls, rice floral organs, such as anthers and ovaries, remain alive; even in mature smut balls, greenish and alive ovaries can be observed (Fan et al., 2015; Tang et al., 2013; Zhang et al., 2010). However, cell death may be inevitably induced in filaments in which the host cells seem to be replaced by hyphae under microdissection at the late infection stage (Tang et al., 2013). Overall, $\mathrm{Vv}$ shows no necrotrophic growth during the entire infection and acquires nutrients from living host tissues, whilst maintaining them alive even longer. Thus, Vv is classified as a biotroph. Similar to some biotrophs, such as Claviceps purpurea (Tudzynski and Scheffer, 2004), Vv can be cultivated in axenic cultures, greatly facilitating scientific research.

The pedicel connects a rice spikelet and the main stem of a panicle. Histological examinations of diseased panicles have indicated that $\mathrm{V} v$ hyphae cannot extend into pedicel and stem tissues, 
and no anatomical changes in the pedicel can be detected (Li W. et al., 2013; Tang et al., 2013). It is indicated that flower infection is not caused by $\mathrm{Vv}$ moving through vascular tissues. It has been reported that $\mathrm{V} v$ also attacks rice coleoptiles intercellularly at the early germination stage and rice roots at the seedling stage, leading to asymptomatic colonization (Ikegami, 1962a,b, 1963a; Schroud and TeBeest, 2005; TeBeest, 2010). In addition, the presence of $\mathrm{Vv}$ in different tissues of rice plants can be detected after coleoptile and root infections (Ikegami, 1963b; TeBeest, 2010). However, the direct relation between coleoptile or root infection and the formation of false smut balls in the panicle has not been clarified. Overall, these findings indicate that $\mathrm{V}$-induced disease is not systemic, although the pathogen can infect some other tender tissues, including rice coleoptiles (Ikegami, 1962a,b, 1963b), roots of germinated seedlings (Schroud and TeBeest, 2005) and young Arabidopsis leaves in occasional cases (Fan et al., 2014), in addition to flower filaments (Hu et al., 2013; Tang et al., 2013).

\section{GENOMICS AND GENETICS}

$\mathrm{Vv}$ can grow in axenic cultures, although mycelial growth is very slow in solid medium, e.g. the colony diameter is approximately $20 \mathrm{~mm}$ after 7 days of culture in potato sucrose agar (PSA) medium (Fu et al., 2013). Carbon sources, such as sucrose, glucose and starch, favour the mycelial growth of $V v_{\text {, whereas }}$ ammonium sulfate, ammonium nitrate and ammonium chloride are the preferential nitrogen sources (Fu et al., 2013; Wang and Chen, 2013; Zhang Y. et al., 2014). Vv conidiospores are mononuclear, whereas somatic hyphae are multinuclear (Fu et al., 2012). It is still controversial whether $\mathrm{Vv}$ is homothallic or heterothallic (Fu et al., 2014; Yu J. J. et al., 2015). Owing to its ability for axenic growth, considerable advances in $\mathrm{V} v$ genomics and genetics have been achieved.

\section{Vv genome}

The availability of the $\mathrm{Vv}$ genome can largely facilitate the investigation of this pathogen. Wang et al. (2013) constructed a deepcoverage Bacterial Artificial Chromosome (BAC) library of the strain UV-8b, providing general genome information for $\mathrm{Vv}$. In more detail, Zhang Y. et al. (2014) sequenced the same strain, UV- $8 \mathrm{~b}$, using the Roche 454 sequencing platform, and obtained a 39.4-Mb draft genome sequence, which encodes 8426 predicted proteins. Intriguingly, $\mathrm{V} v$ shares the closest evolutionary relationship with the entomopathogenic Metarhizium spp., indicating potential host jumping across plant and animal kingdoms (Kepler et al., 2012; Zhang Y. et al., 2014). Analysis of the Vv genome sequence shows that it has relatively fewer gene inventories for nutrient uptake, polysaccharide degradation and secondary metabolism, but is enriched with genes for secreted proteins and secondary metabolism, which may be associated with its biotrophic lifestyle and flower-specific infection (Zhang Y. et al., 2014).
In addition, the Vv genome encodes 628 potentially secreted proteins, including 193 putative effectors; however, their roles in pathogen-host interactions are largely unknown (Zhang Y. et al., 2014).

Mycotoxins may be important during pathogenesis. Based on the sequenced genome, it is predicted that non-ribosomal peptide synthetase (NRPS) and polyketide synthase (PKS) gene clusters may be responsible for the biosynthesis of the two Vv mycotoxins, ustiloxin and ustilaginoidin, respectively (Fu et al., 2015a; Koiso et al., 1994; Lu et al., 2015; Meng et al., 2015; Nakamura et al., 1994; Shan et al., 2012, 2013, 2014; Zhang Y. et al., 2014). By contrast, Tsukui et al. (2015) suggested that ustiloxins from Vv are ribosomally synthesized, according to homology analysis with the biosynthetic gene cluster for ustiloxin B from Aspergillus flavus. However, experimental evidence is needed to confirm gene clusters for ustiloxin production in Vv. A recent report has indicated that the mycotoxins generated in the rice false smut balls on infected rice panicles could be different from those in the cultured fungal mass, and some novel ustilaginoidins have been identified only from the fungus on solid rice medium (Lu et al., 2015). In addition, five main ustilaginoidins show differential distribution patterns together with the development of the false smut ball (Meng et al., 2015). These observations raise the question of whether ustiloxins and/or ustilaginoidins play a role in epiphytic growth and pathogenicity.

\section{Genetic diversity}

Recent reports applying genomic and transcriptomic data have revealed single nucleotide polymorphism (SNP) and simple sequence repeat (SSR) markers for the identification of $\mathrm{Vv}$ genetic diversity (Jia et al., 2015; Sun et al., 2013; Yu et al., 2014). Earlier studies using PCR-based approaches, such as rDNA-ITS variability (Wang et al., 2009), amplified fragment length polymorphism (AFLP) (Zhou et al., 2008) and random amplification of polymorphic DNA (RAPD) (Li et al., 2012), have identified very limited genetic diversity of $\mathrm{Vv}$. However, three SNP-rich genomic regions have been identified by comparative genomics (Sun et al., 2013). Based on the analysis of the three SNP-rich genomic regions, significant genetic diversifications were detected among populations from five major rice production areas in China, and isolates from the same area showed considerable DNA composition stability (Sun et al., 2013), which is consistent with the conjecture that Vv may not be an air-borne, but a water- and/or soil-borne pathogen. Consistent with this speculation, Wang et al. (2014) reported that geography is more important than rice cultivar in constructing the genetic diversity of $\mathrm{Vv}$. Moreover, there is no significant association between rice cultivars and Vv diversity (Pan et al., 2006). Nevertheless, different spikelets in a rice panicle can be infected by different $\mathrm{V} v$ isolates, and one spikelet can be infected by one or multiple $\mathrm{Vv}$ isolates (Yu et al., 2013), although it is unclear 
whether the pathogenicity of genetically different isolates is different. Interestingly, genetic divergence is generally higher in isolates from inland areas than from coastal areas (Wang et al., 2012). Genetic variation in north-east China is relatively low, which may be a result of less active sexual reproduction (Sun et al., 2013).

\section{Genetic transformation}

Several procedures for the generation of GFP-tagged transgenic $\mathrm{V}_{\mathrm{V}}$ strains have been reported (Ashizawa et al., 2012; Tanaka et al., 2011; Yu M. et al., 2015; Zhang et al., 2006). Principles should be applied for the examination of the $\mathrm{Vv}$ transformants obtained: they must be able to infect rice flowers and cause the featured disease symptoms, i.e. false smut balls. By electroporation of intact Vv conidial cells with the linearized transformation vector pCB1004eGFP, Tanaka et al. (2011) successfully obtained enhanced GFP (eGFP)-expressing transformants. Ashizawa et al. (2012) also developed a GFP-labelled Vv strain by polyethyleneglycol-mediated protoplast transformation. Using Agrobacterium tumefaciens-mediated transformation (ATMT), Zhang et al. (2006) successfully engineered a GFP-labelled Vv strain. The hygromycin resistance gene was used as a selection marker, because $150 \mu \mathrm{g} /$ $\mathrm{mL}$ hygromycin B can completely inhibit $\mathrm{Vv}$ growth. Yu M. et al. (2015) also constructed a GFP-tagged Vv strain that largely facilitated the investigation of the Vv infection process (Fan et al., 2014; Yu M. et al., 2015). With an optimized ATMT procedure in $\mathrm{Vv}, \mathrm{Yu}$ M. et al. (2015) generated a T-DNA insertion library of 5600 hygromycin-resistant $\mathrm{Vv}$ transformants, and identified 37 pathogenicity-impaired mutants. Among the 37 mutants, B20, which is disrupted in the UVSUN2 gene, showed deficiency in virulence, stress response, conidial morphology and hyphal growth (Yu M. et al., 2015).

\section{MOLECULAR Vv-RICE INTERACTIONS}

Vv biotrophically infects rice flowers and forms false smut balls, which are the only symptoms visible to the naked eye. The size of a false smut ball is usually several times larger than that of a mature rice seed, indicating that many nutrients are needed for the formation of false smut balls. Intriguingly, Vv also attacks barley flowers, but does not form a ball-like colony (Hu et al., 2013). Therefore, the formation of false smut balls must require specific interactions between $\mathrm{V} v$ and rice. Two aspects are discussed here: host responses to $\mathrm{V} v$ infection and $V v$ virulence factors.

\section{Host responses to $\mathbf{V v}$ infection}

Transcriptomic analyses have identified a number of rice genes modulated by $\mathrm{V} v$ infection. In the compatible interaction between the rice cultivar 93-11 and the $\mathrm{Vv}$ isolate Guangxi-2, rice genes involved in phosphorylation, programmed cell death and cell wall biogenesis are differentially expressed (Chao et al., 2014). WRKY- and Myb-regulated genes are overexpressed, whereas abscisic acid (ABA)- and $\mathrm{Ca}^{2+}$-regulated genes are repressed (Chao et al., 2014). Moreover, several genes specific to pollen development are down-regulated in VV-infected rice spikelets, but do not respond to stresses, such as heat, cold, salt, drought, submergence, Magnaporthe oryzae or Xanthomonas oryzae pv. oryzae infection (Chao et al., 2014). These observations suggest that pollen development genes play a role in unique $\mathrm{V}_{\mathrm{V}}$-rice interactions. Comparative transcriptomic analysis of resistant 'IR28' and susceptible ' $H X Z$ ' rice cultivars in response to $\mathrm{V} v$ infection revealed that many genes involved in secondary metabolites and hormone metabolism, and genes encoding flavin-containing monooxygenases and peroxidases, are differentially regulated in resistant and susceptible cultivars (Yang et al., 2014). Furthermore, Han et al. (2015) suggested that the resistant cultivar 'IR28' has the ability to suppress the expression of pathogenicity genes in $V v_{\text {, and }}$ 'IR28' genes involved in the production of pathogenesis-related proteins and diterpene phytoalexins may contribute to rice false smut resistance.

Because there are only certain percentages of inoculated spikelets that are infected by $V v$, responses in non-infected spikelets may be different from those in infected ones. Thus, host responses detected from samples collected after artificial inoculation could be a systemic consequence if non-infected spikelets outnumber infected ones. By sampling the spikelets that are obviously $\mathrm{VV}$ infected, a transcriptomic analysis revealed that a number of grain-filling-related genes are highly activated, whereas, in noninfected spikelets, these genes are only activated after fertilization (Fan et al., 2015). Moreover, preliminary transcriptional data showed over nine-fold up-regulation of the Abscisic acidinsensitive 3 ( $A B \mid 3$ ) gene (LOC_Os01g68370) in Vv-infected spikelets (Fan et al., 2015). ABI3 plays important roles in ABA signalling and in the regulation of seed-specific development, and ectopic expression of $A B I 3$ can induce the expression of a large number of seed-specific genes (Suzuki et al., 2003). Thus, this gene may be involved in the activation of the grain-filling network during the $\mathrm{V} v$-rice interaction. We speculate that $\mathrm{V} v$ may hijack the host nutrient reservoir by mimicking fertilization and activating the grain-filling network, extracting nutrients towards colonization sites for growth and for the formation of false smut balls. Consistent with this hypothesis, a recent study has shown that mild $\mathrm{Vv}$ infection (one to two false smut balls per diseased panicle) can enhance rice yield attributes, such as the filled grain number and grain weight (Dhua et al., 2015). Similar results were presented in the data provided by Nessa et al. (2015). Dhua et al. (2015) also observed that small false smut balls (average ball weight of less than $40 \mathrm{mg}$ ) tended to be produced in tolerant rice cultivars. It will be interesting to address the underlying mechanism in the future. As a stamen filament-infecting fungus, $\mathrm{Vv}$ is challenged by the risk that the rice filament is short lived. Our recent work 


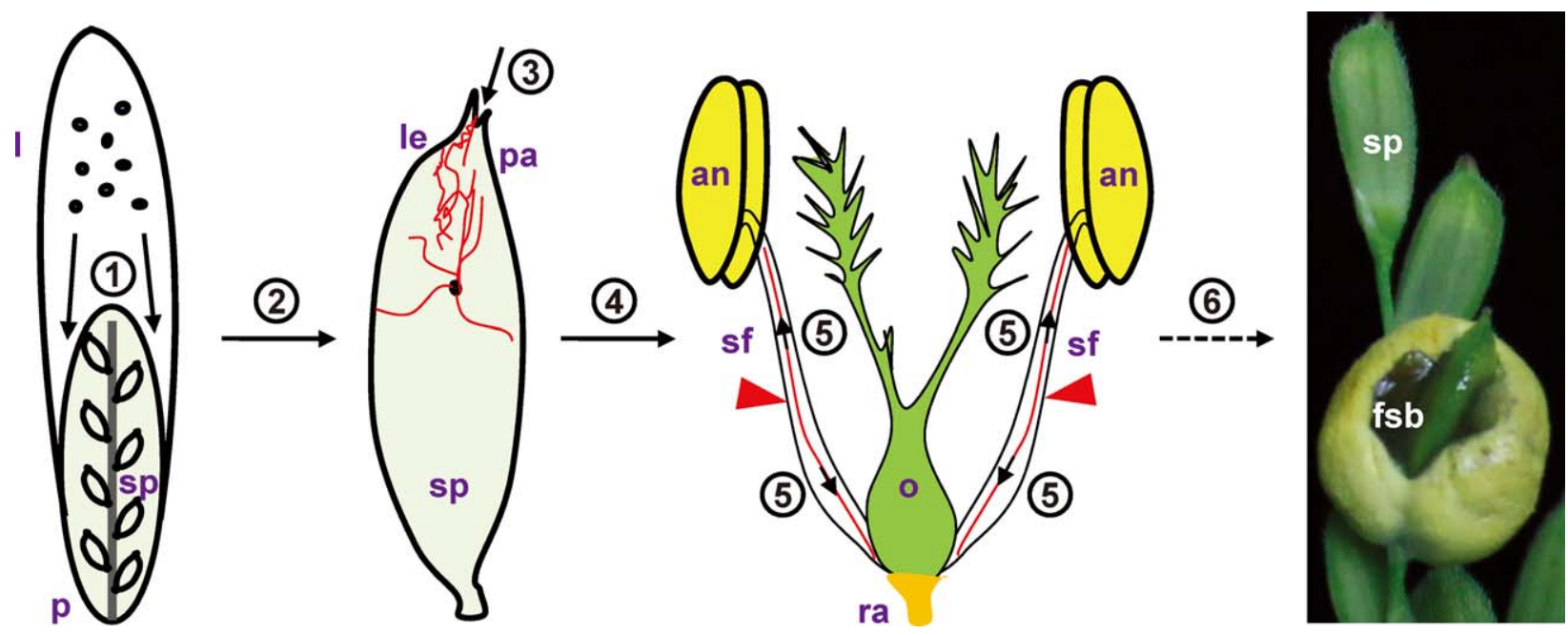

Fig. 3 A schematic diagram showing how Villosiclava virens (Vv) converts a rice spikelet to a false smut ball. Vv spores landing on the top of the second leaf (I) can enter the developing panicle (p) along with rainwater (1)). Subsequently, Vv spores are attached to the developing spikelet (sp) and germinate to produce hyphae (2)). The hyphae extend into the inner space of the spikelet via the gap between the palea (pa) and lemma (le) (3)). Primary infection sites are found in the stamen filaments (sf) (4)), where the hyphae extend intercellularly in both directions ((5)). Hyphae can extend into anthers (an) and reach the rachilla (ra), and intertwine with the ovary (o) and other floral organs. Vv hyphae acquire abundant nutrients to form false smut balls (fsb), hypothetically through hijacking of the rice nutrient reservoir (6)). This step (arrow with dotted line) is of particular interest and requires further exploration. Red curved lines represent Vv hyphae. Red arrowheads point to the primary infection sites at the stamen filaments.

shows that flower opening and related genes are suppressed in Vv-infected spikelets (Fan et al., 2015), indicating that Vv may have the ability to maintain colonization sites by inhibiting rice from flowering.

\section{Vv virulence factors}

Effectors are essential virulence factors employed by pathogens for the colonization of hosts. Combining genomic and transcriptomic data, a number of genes with potential roles in $\mathrm{Vv}$ pathogenicity and the pathogen-host interaction have been predicted. These genes are highly enriched in the transcriptome during the early infection of rice (Zhang Y. et al., 2014). The Vv genome encodes at least 193 putative effectors, 18 of which have been identified to suppress plant hypersensitive responses (Zhang Y. et al., 2014). As a biotroph, Vv may need to express some of these effectors to subvert rice innate immunity for successful infection. RNA silencing is a major defence mechanism against pathogens in plants (Ding, 2010; Vance and Vaucheret, 2001), whereas pathogens can secrete effectors to suppress the RNA silencing system of plants, such as PSR1 and PSR2 from Phytophthora sojae (Qiao et al., 2013). Effectors with similar functions may also exist in Vv. For instance, Nicotiana benthamiana transient expression screening reveals that Uv_5823 has an effect in the suppression of gene silencing (Fang, 2014). A T-DNA insertion library of $\mathrm{Vv}$ has been established and dozens of pathogenicity-deficient mutants have been identified (Yu M. et al., 2015). The characterization of the responsible genes of these mutants will add important information to the molecular mechanism of $\mathrm{V} v$ pathogenicity.

\section{CONCLUSIONS AND OUTLOOK}

In the past few years, we have witnessed dramatic progress towards the understanding of the rice false smut pathogen. Cytological and molecular approaches have revealed the process of how Vv converts a rice spikelet into a false smut ball (Fig. 3). At the rice booting stage, $V v$ spores first need to enter the leaf sheath, and land on the developing spikelet (Fig. 3, (1), (2)). Spores germinate on the outer surface of the spikelet and the elongated hyphae extend into the inner space of the rice spikelet through the gap between the lemma and the palea (Fig. 3, (3)) (Ashizawa et al., 2012). The hyphae specifically infect stamen filaments, inhibit rice flowering and intercept seed formation (Fig. 3, (4), (5)) (Fan et al., 2015; Tang et al., 2013); meanwhile, Vv infection induces the expression of rice grain-filling genes which may be pivotal for the development of the false smut ball (Fig. 3, (6)) (Fan et al., 2015). These findings lead to three important considerations for future research on false smut resistance and Vv pathogenesis: (i) the water-proof degree of the rice sheath at the booting stage; (ii) the aperture size between the lemma and palea of the rice spikelet; and (iii) the ability of Vv to acquire sufficient nutrients for false smut ball formation. In addition, current knowledge indicates the blastogenesis and epiphytic characteristics of $\mathrm{V} v$ under wet conditions, which may play a role in epidemic occurrence of false smut disease when the rice booting stage coincides with rainy days 
(Fan et al., 2014). The available genomic information and genetic engineering tools provide an important basis to unravel the mysteries of $\mathrm{Vv}$ life.

Despite the above progress, some important questions need to be addressed to better understand the interactions between $\mathrm{Vv}$ and rice. How does $\mathrm{Vv}$ turn the host floral organ into a nutrient supplier to form false smut balls? Are the floral organs, such as the filament and ovary, essential for $\mathrm{Vv}$ infection? Are there any links between specific effectors and mycotoxins with $\mathrm{V} v$ epiphytic growth or flower colonization? Are there any resistance genes in rice that can mount an immune response against $\mathrm{V} v$ ? The identification of pathogen factors that activate rice grain-filling genes and the application of floral mutants and resistant germplasm should be valuable in addressing some of these questions. In addition, mycoviruses infecting Vv are widespread (Jiang et al., 2014, 2015; Zhang et al., 2013a,b; Zhang T. et al., 2014; Zhong et al., 2014a,b,c; Zhu et al., 2015). Whether mycoviruses affect the virulence of $\mathrm{Vv}$ is also an interesting question. Overall, Vv-rice interplay is an interesting specific pathosystem and any progress obtained should enrich our knowledge of host-pathogen interactions and biotrophic fungi.

\section{ACKNOWLEDGEMENTS}

We have no conflicts of interest to declare. Our work on the rice false smut pathogen was supported by the Sichuan Agricultural University Start-up packages awarded to J. Fan and W. Wang, and a grant from the National Natural Science Foundation of China (31501598) to J. Fan. We thank our colleague S. Li for providing seeds of the rice male-sterile mutant abcg15. We thank D. W. Hu for helpful discussions and collecting some of the literature. We thank X. Wang for critical reading of the manuscript.

\section{REFERENCES}

Ahonsi, M.O. and Adeoti, A.Y.A. (2003) Evaluation of fungicides for the control of false smut of rice caused by Ustilaginoidea virens (Cooke) Tak. J. Agric. Res. 4, 118-122.

Ashizawa, T. and Kataoka, Y. (2005) Detection of Ustilaginoidea virens in rice panicles before and after heading in the field using nested-PCR technique with species-specific primers. Jpn. J. Phytopathol. 71, 16-19 (in Japanese with English abstract).

Ashizawa, T., Takahashi, M., Moriwaki, J. and Hirayae, K. (2010) Quantification of the rice false smut pathogen Ustilaginoidea virens from soil in Japan using realtime PCR. Eur. J. Plant Pathol. 128, 221-232.

Ashizawa, T., Takahashi, M., Arai, M. and Arie, T. (2012) Rice false smut pathogen, Ustilaginoidea virens, invades through small gap at the apex of a rice spikelet before heading. J. Gen. Plant Pathol. 78, 255-259.

Atia, M.M.M. (2004) Rice false smut (Ustilaginoidea virens) in Egypt. J. Plant Dis. Prot. 111, 71-82.

Bischoff, J.F., Sullivan, R.F., Kjer, K.M. and White, J.F., Jr. (2004) Phylogenetic placement of the anamorphic tribe Ustilaginoideae (Hypocreales, Ascomycota). Mycologia, 96, 1088-1094.

Biswas, A. (2001) False smut disease of rice: a review. Environ. Ecol. 19, 67-83.

Brooks, S.A., Anders, M.M. and Yeater, K.M. (2009) Effect of cultural management practices on the severity of false smut and kernel smut of rice. Plant Dis. 93, 1202-1208.

Brooks, S.A., Anders, M.M. and Yeater, K.M. (2010) Effect of furrow irrigation on the severity of false smut in susceptible rice varieties. Plant Dis. 94, 570-574.
Bonman, J. M. (1992) Blast. In: Compendium of rice diseases. (Webster, R. K. and Gunnell, P. S., eds.). St. Paul, MN: The American Phytopathological Society, pp. 14-16.

Chao, J., Jin, J., Wang, D., Han, R., Zhu, R., Zhu, Y. and Li, S. (2014) Cytological and transcriptional dynamics analysis of host plant revealed stage-specific biological processes related to compatible rice-Ustilaginoidea virens interaction. PLoS One, 9, e91391.

Chen, L., Hu, D., Chen, M. and Zhang, J. (2007) SEM observation of rice false smut balls and colony microstructure of Ustilaginoidea virens. Mycosystema, 26, 89-96.

Chib, H.S., Tikoo, M.L., Kalha, C.S., Gupta, B.R., Singh, S.K. and Raina, P.K. (1992) Effect of false smut on yield of rice. Indian J. Mycol. Plant Pathol. 22, 278-280.

Deng, Q. (2015) Research on the role of sclerotium in the life cycle of Villosiclava virens in nature. Hangzhou: Institute of Biotechnology, Zhejiang University.

Deng, Q., Yong, M., Li, D., Lai, C., Chen, H., Fan, J. and Hu, D. (2015) Survey and examination of the potential alternative hosts of Villosiclava virens, the pathogen of rice false smut, in China. J. Integr. Agric. 14, 1332-1337.

Dhua, U., Dhua, S.R. and Sahu, R.K. (2015) Precise disease severity assessment for false smut disease of rice. J. Phytopathol. 163, 931-940. doi: 10.1111/jph.12395.

Ding, S.W. (2010) RNA-based antiviral immunity. Nat. Rev. Immunol. 10, 632-644.

Ditmore, M. and TeBeest, D.0. (2005) Detection of seed-borne Ustilaginoidea virens by nested-PCR. In: B. R. Wells Rice Research Studies 2005 (Norman, R.J., Meullenet, J.-F. and Moldenhauer, K.A.K., eds), pp. 121-125. Fayetteville, AR: University of Arkansas Agricultural Experiment Station Research Series.

Ditmore, M., Moore, J.W. and TeBeest, D.0. (2006) Infection of plants of selected rice cultivars by the false smut fungus, Ustilaginoidea virens, in Arkansas. In: $B . R$. Wells Rice Research Studies 2005 (Norman, R.J., Meullenet, J.-F. and Moldenhauer, K.A.K., eds), pp. 132-138. Fayetteville, AR: University of Arkansas Agricultural Experiment Station Research Series.

Dong, K. and Fu, S. (1989) Sprouting test on sclerotia of rice false smut. J. Shenyang Agric. Univ. 20, 359-362.

Fan, J., Guo, X.-Y., Huang, F., Li, Y., Liu, Y.-F., Li, L., Xu, Y.-J., Zhao, J.-Q., Xiong, H., Yu, J.-J. and Wang, W. (2014) Epiphytic colonization of Ustilaginoidea virens on biotic and abiotic surfaces implies the widespread presence of primary inoculum for rice false smut disease. Plant Pathol. 63, 937-945.

Fan, J., Guo, X.Y., Li, L., Huang, F., Sun, W.X., Li, Y., Huang, Y.Y., Xu, Y.J., Shi, J., Lei, Y., Zheng, A.P. and Wang, W.M. (2015) Infection of Ustilaginoidea virens intercepts rice seed formation but activates grain-filling-related genes. J. Integr. Plant Biol. 57, 577-590.

Fan, R., Wang, Y., Liu, B., Zhang, J., Wang, H. and Hu, D. (2010) The process of asexual spore formation and examination of chlamydospore germination of Ustilaginoidea virens. Mycosystema, 29, 188-192.

Fang, A. (2014) Screening and identification of the Ustilaginoidea virens effectors that can induce or suppress plant immunity. Beijing: College of Agriculture and Biotechnology, China Agricultural University.

Fu, R., Ding, L., Zhu, J., Li, P. and Zheng, A. (2012) Morphological structure of propagules and electrophoretic karyotype analysis of false smut Villosiclava virens in rice. J. Microbiol. 50, 263-269.

Fu, R., Yin, C., Liu, Y., Ding, L., Zhu, J., Zheng, A. and Li, P. (2013) The influence of nutrient and environmental factors on mycelium growth and conidium of false smut Villosiclava virens. Afr. J. Microbiol. Res. 7, 825-833.

Fu, R., Yin, C., Deng, Q., Li, P. and Zheng, A. (2014) Mating type loci analysis indicates that Villosiclava virens, the causal agent of false smut disease of rice, is a homothallic fungus. Trop. Plant Pathol. 39, 203-209.

Fu, X., Wang, A., Wang, X., Lin, F., He, L., Lai, D., Liu, Y., Li, Q.X., Zhou, L. and Wang, B. (2015a) Development of a monoclonal antibody-based indirect competitive ELISA for detection of ustiloxin B in rice false smut balls and rice grains. Toxins, 7, 3481-3496.

Fu, X., Wang, X., Cui, Y., Wang, A., Lai, D., Liu, Y., Li, Q.X., Wang, B. and Zhou, L. (2015b) A monoclonal antibody-based enzyme-linked immunosorbent assay for detection of ustiloxin A in rice false smut balls and rice samples. Food Chem. 181, 140-145.

Gao, B.D. and Zhong, J. (2011) Research advances in infection process of Ustilaginoidea virens. Hunan Agric. Sci. 2011, 93-97.

Gao, J., Han, M. and Zhang, X. (2010) Study on control effects of several pesticides on rice false smut. J. Hebei Agric. Sci. 14, 76-77.

Guo, X., Li, Y., Fan, J., Li, L., Huang, F. and Wang, W. (2012) Progress in the study of false smut disease in rice. J. Agric. Sci. Technol. A, 2, 1211-1217.

Han, Y., Zhang, K., Yang, J., Zhang, N., Fan, A., Zhang, Y., Liu, Y., Chen, Z., Hsiang, T. and Sun, W. (2015) Differential expression profiling of the early 
response to Ustilaginoidea virens between false smut resistant and susceptible rice varieties. BMC Genomics, 16, 955.

Honkura, R. and Kimura, Y. (1988) Some notes on the spore dispersal and the period of infection of rice false smut pathogenic fungus. Ann. Rep. Prot. North Jpn, 39, 88-91.

Hu, D.W., Tang, Y.X. and Yong, M.L. (2013) Rice false smut is a stamen filamentinfected disease. In: 10th International Congress of Plant Pathology. (Peng, Y., ed.) Beijing: Chinese Society for Plant Pathology, pp. 123

Hu, M., Luo, L., Wang, S., Liu, Y. and Li, J. (2014) Infection processes of Ustilaginoidea virens during artificial inoculation of rice panicles. Eur. J. Plant Pathol. 139, 67-77.

Huang, F., Li, Y., Shi, J., Fan, J., Xu, Y.-J. and Wang, W.-M. (2015) Screening and polymorphism analysis of rice germplasms for resistance to false smut disease in Sichuan Province. Acta Phytopathol. Sin. in press.

Ikegami, H. (1960) Studies on the false smut of rice IV. Infection of the false smut due to inoculation with chlamydospores and ascospores at the booting stage of rice plants. Res. Bull. Fac. Agric. Gifu Univ. 12, 45-51.

Ikegami, H. (1961) Studies on the false smut of rice VII. Analysis on the occurrence of the smut balls at the different ages. Res. Bull. Fac. Agric. Gifu Univ. 14, 27-37.

Ikegami, H. (1962a) Microscopic observation of hyphae in tissues of tillering rice plants inoculated with chlamydospores of the false smut fungus at seedling stage. Ann. Phytopathol. Soc. Jpn. 28, 297.

Ikegami, H. (1962b) Studies on the false smut of rice. V. Seedling inoculation with the chlamydospores of the false smut fungus. Ann. Phytopathol. Soc. Jpn. 27, $16-23$.

Ikegami, H. (1963a) Occurrence and development of sclerotia of the rice false smut fungus. Res. Bull. Fac. Agric. 18, 47-53.

Ikegami, H. (1963b) Studies on the false smut of rice. X. Invasion of chlamydospores and hyphae of the false smut fungus into rice plants. Res. Bull. Fac. Agric. Gifu Univ. 18, 54-60.

Jecmen, A.C. and TeBeest, D.0. (2015) First report of the occurrence of a white smut infecting rice in Arkansas. J. Phytopathol. 163, 138-143.

Ji, F., Cao, H., Xu, J., Yin, X. and Shi, J. (2012) Simultaneous quantitative determination of ustiloxin $A$ and ustiloxin $D$ in rice grains by high performance liquid chromatography-tandem mass spectrometry. Chin. J. Rice Sci. 26, 246-250.

Jia, Q., Gu, Q., Zheng, L., Hsiang, T., Luo, C. and Huang, J. (2015) Genetic analysis of the population structure of the rice false smut fungus, Villosiclava virens, in China using microsatellite markers mined from a genome assembly. Plant Pathol. 64, 1440-1449. dpi: 10.1111/ppa.12373.

Jiang, Y., Luo, C., Jiang, D., Li, G. and Huang, J. (2014) The complete genomic sequence of a second novel partitivirus infecting Ustilaginoidea virens. Arch. Virol. 159, 1865-1868.

Jiang, Y., Zhang, T., Luo, C., Jiang, D., Li, G., Li, Q., Hsiang, T. and Huang, J. (2015) Prevalence and diversity of mycoviruses infecting the plant pathogen Ustilaginoidea virens. Virus Res. 195, 47-56.

Jiang, Z., Jiang, Z., Jiang, Z. and Zhang, G. (2009) Effect of false smut ball number on yield of rice. Northern Rice, 39, 53-54.

Kepler, R.M., Sung, G.H., Harada, Y., Tanaka, K., Tanaka, E., Hosoya, T., Bischoff, J.F. and Spatafora, J.W. (2012) Host jumping onto close relatives and across kingdoms by Tyrannicordyceps (Clavicipitaceae) gen. nov. and Ustilaginoidea (Clavicipitaceae). Am. J. Bot. 99, 552-561.

Kim, K.W. and Park, E.W. (2007) Ultrastructure of spined conidia and hyphae of the rice false smut fungus Ustilaginoidea virens. Micron, 38, 626-631.

Koiso, Y., Li, Y., Iwasaki, S., Hanaoka, K., Kobayashi, T., Sonoda, R., Fujita, Y., Yaegashi, H. and Sato, Z. (1994) Ustiloxins, antimitotic cyclic peptides from false smut balls on rice panicles caused by Ustilaginoidea virens. J. Antibiot. (Tokyo), 47, 765-773.

Ladhalakshmi, D., Laha, G.S., Singh, R., Karthikeyan, A., Mangrauthia, S.K., Sundaram, R.M., Thukkaiyannan, P. and Viraktamath, B.C. (2012) Isolation and characterization of Ustilaginoidea virens and survey of false smut disease of rice in India. Phytoparasitica, 40, 171-176.

Li, H., Ni, D.H., Duan, Y.B., Chen, Y., Li, J., Song, F.S., Li, L., Wei, P.C. and Yang, J.B. (2013) Quantitative detection of the rice false smut pathogen Ustilaginoidea virens by real-time PCR. Genet. Mol. Res. 12, 6433-6441.

Li, W., Li, L., Feng, A., Zhu, X. and Li, J. (2013) Rice false smut fungus, Ustilaginoidea virens, inhibits pollen germination and degrades the integuments of rice ovule. Am. J. Plant Sci. 4, 2295-2304.

Li, Y., Liu, Y., Zhang, R., Yu, M. and Chen, Z. (2012) Genetic diversity of Ustilaginoidea virens from rice in Jiangsu province. Jiangsu J. Agric. Sci. 28, 296301.
Liang, Y., Zhang, X., Li, D., Huang, F., Hu, P. and Peng, Y. (2014) Integrated approach to control false smut in hybrid rice in Sichuan Province, China. Rice Sci. 21, 354-360.

Lu, S., Sun, W., Meng, J., Wang, A., Wang, X., Tian, J., Fu, X., Dai, J., Liu, Y., Lai, D. and Zhou, L. (2015) Bioactive bis-naphtho-gamma-pyrones from rice false smut pathogen Ustilaginoidea virens. J. Agric. Food Chem. 63, 35013508

Meng, J., Sun, W., Mao, Z., Xu, D., Wang, X., Lu, S., Lai, D., Liu, Y., Zhou, L. and Zhang, G. (2015) Main ustilaginoidins and their distribution in rice false smut balls. Toxins, 7, 4023-4034.

Miao, Q. (1993) Studies on evaluation technique for the varietal resistance to seedborne rice false smut. J. Yunnan Agric. Univ. 3, 209-212.

Miao, Q. (1994) Studies on the sclerotium of Ustilaginoidea virens (Cooke) Tak J. Yunnan Agric. Univ. 9, 101-104.

Miyazaki, S., Matsumoto, Y., Uchihara, T. and Morimoto, K. (2009) High-performance liquid chromatographic determination of ustiloxin $\mathrm{A}$ in forage rice silage. J. Vet. Med. Sci. 71, 239-241.

Nakamura, K., Izumiyama, N., Ohtsubo, K., Koiso, Y., Iwasaki, S., Sonoda, R., Fujita, Y., Yaegashi, H. and Sato, Z. (1994) "Lupinosis"-like lesions in mice caused by ustiloxin, produced by Ustilaginoidea virens: a morphological study. Nat. Toxins, 2, 22-28.

Nessa, B., Salam, M.U., Haque, A.H.M.M., Biswas, J.K., MacLeod, W.J., Ali, M.A., Halder, K.P. and Galloway, J. (2015) FLYER: a simple yet robust model for estimating yield loss from rice false smut disease (Ustilaginoidea virens). Am. J. Agric. Biol. Sci. 10, 41-54.

Ono, K. and Uehara, K. (1949) Damages of rice by false smut disease. Agric. Hortic. 24, 489-490.

Osada, S. (1995) Effect of false smut occurrence on yield and quality of rice. Ann Rep. Plant Prot. North Jpn. 46, 30-32.

Pan, Y.J., Fan, J.J., Fu, B., Wang, J., Xu, J., Chen, H., Li, Z. and Zhou, Y. (2006) Genetic diversity of Ustilaginoidea virens revealed by AFLP I: genetic structure of the pathogen in a field. Acta Phytopathol. Sin. 36, 337-341.

Qiao, Y., Liu, L., Xiong, Q., Flores, C., Wong, J., Shi, J., Wang, X., Liu, X. Xiang, Q., Jiang, S., Zhang, F., Wang, Y., Judelson, H.S., Chen, X. and Ma, W. (2013) Oomycete pathogens encode RNA silencing suppressors. Nat. Genet. 45, 330-333.

Qin, P., Tu, B., Wang, Y., Deng, L., Quilichini, T.D., Li, T., Wang, H., Ma, B. and Li, S. (2013) ABCG15 encodes an ABC transporter protein, and is essential for postmeiotic anther and pollen exine development in rice. Plant Cell Physiol. 54, 138-154.

Schroud, P. and TeBeest, D.O. (2005) Germination and infection of rice roots by spores of Ustilaginoidea virens. AAES Res. Ser. 540, 143-151.

Shan, T., Sun, W., Liu, H., Gao, S., Lu, S., Wang, M., Sun, W., Chen, Z., Wang, S. and Zhou, L. (2012) Determination and analysis of ustiloxins A and B by LC-ESIMS and HPLC in false smut balls of rice. Int. J. Mol. Sci. 13, 11 275-11 287.

Shan, T., Sun, W., Wang, X., Fu, X., Sun, W. and Zhou, L. (2013) Purification of ustiloxins $\mathrm{A}$ and $\mathrm{B}$ from rice false smut balls by macroporous resins. Molecules, 18 8181-8199.

Shan, T., Wang, X., Fu, X., Meng, J., Sun, W., Wang, A., Liu, Y. and Zhou, L. (2014) Optimization of extraction process for ustiloxins $A$ and $B$ from rice false smut balls using an orthogonal array design. Afr. J. Biotechnol. 13, 3912-3918.

Shetty, S.A. and Shetty, H.S. (1985) An alternative host for Ustilaginoidea virens (Cooke) Takahashi. IRRI Newslett. 10, 11

Shetty, S.A. and Shetty, H.S. (1987) Role of Panicum trypheron in annual recurrence of false smut of rice. Trans. Br. Mycol. Soc. 88, 409-411.

Singh, A.K. and Pophaly, D.J. (2010) An unusual rice false smut epidemic reported in Raigarh District, Chhattisgarh, India. Int. Rice Res. Notes, 35, 1-3.

Singh, R.A. and Dubey, K.S. (1984) Sclerotial germination and ascospore formation of Claviceps oryzae-sativae in India. Indian Phytopathol. 37, 168-170.

Sun, X., Kang, S., Zhang, Y., Tan, X., Yu, Y., He, H., Zhang, X., Liu, Y., Wang, S., Sun, W., Cai, L. and Li, S. (2013) Genetic diversity and population structure of rice pathogen Ustilaginoidea virens in China. PLoS One, 8, e76879.

Suzuki, M., Ketterling, M.G., Li, Q.B. and McCarty, D.R. (2003) Viviparous1 alters global gene expression patterns through regulation of abscisic acid signaling. Plant Physiol. 132, 1664-1677.

Tanaka, E., Ashizawa, T., Sonoda, R. and Tanaka, C. (2008) Villosiclava virens gen. nov., comb. nov., the teleomorph of Ustilaginoidea virens, the causal agent of rice false smut. Mycotaxon, 106, 491-501.

Tanaka, E., Kumagawa, T., Tanaka, C. and Koga, H. (2011) Simple transformation of the rice false smut fungus Villosiclava virens by electroporation of intact conidia. Mycoscience, 52, 344-348. 
Tang, Y.-X., Jin, J., Hu, D.-W., Yong, M.-L., Xu, Y. and He, L.-P. (2013) Elucidation of the infection process of Ustilaginoidea virens (teleomorph: Villosiclava virens) in rice spikelets. Plant Pathol. 62, 1-8.

TeBeest, D. (2010) Infection of rice by Ustilaginoidea virens. Phytopathology, 100, S125.

TeBeest, D.0., Jecmen, A. and Ditmore, M. (2010) Infection of rice by the false smut fungus, Ustilaginoidea virens. In: B. R. Wells Rice Research Studies 2005 (Norman, R.J., Meullenet, J.-F. and Moldenhauer, K.A.K., eds), pp. 70-81. Fayetteville, AR: University of Arkansas Agricultural Experiment Station Research Series.

Tripathi, S., Mishra, P. and Sinha, A.P. (2014) In-vitro evaluation of fungicides against Ustilaginoidea virens (Cke.) Takahashi, the incitant of false smut of rice. Int. J. Basic App. Agric. Res. 12, 379-381.

Tsuda, M., Sasahara, M., Ohara, T. and Kato, S. (2006) Optimal application timing of simeconazole granules for control of rice kernel smut and false smut. J. Gen. Plant Pathol. 72, 301-304.

Tsukui, T., Nagano, N., Umemura, M., Kumagai, T., Terai, G., Machida, M. and Asai, K. (2015) Ustiloxins, fungal cyclic peptides, are ribosomally synthesized in Ustilaginoidea virens. Bioinformatics, 31, 981-985.

Tudzynski, P. and Scheffer, J. (2004) Claviceps purpurea: molecular aspects of a unique pathogenic lifestyle. Mol. Plant Pathol. 5, 377-388.

Vance, V. and Vaucheret, H. (2001) RNA silencing in plants-defense and counterdefense. Science, 292, 2277-2280.

Wang, F., Zhang, S., Liu, M.G., Lin, X.S., Liu, H.J., Peng, Y.L., Lin, Y., Huang, J.B. and Luo, C.X. (2014) Genetic diversity analysis reveals that geographical environment plays a more important role than rice cultivar in Villosiclava virens population selection. Appl. Environ. Microbiol. 80, 2811-2820.

Wang, G. (1988) Studies on the factors influencing the germination of the chlamydospores of Ustilaginoidea virens. Acta Phytopathol. Sin. 15, 241-245.

Wang, G. (1995) The sexual stage of Ustilaginoidea virens and the infection process of ascospores on rice. J. Zhejiang Wanli Univ. Z1, 1-7.

Wang, S. and Bai, Y. (1998) The pathogen of false smut of rice. Acta Phytopathol. Sin. 28, 19-24.

Wang, S.T., Lin, T.B., Gan, L., Shi, N.N., Yang, X.J. and Chen, F.R. (2012) Analysis of cultural characteristics and genetic diversity of Ustilaginoidea virens from some regions in China. Acta Phytophyl. Sin. 39, 217-223.

Wang, W. and Chen, Z. (2013) Biological characterization of Ustilaginoidea virens with different pathogenicity. Southwest China J. Agric. Sci. 26, 2301-2306.

Wang, X., Liu, Q., Wang, H., Luo, C.X., Wang, G. and Luo, M. (2013) A BAC based physical map and genome survey of the rice false smut fungus Villosiclava virens. BMC Genomics, 14, 883.

Wang, Y., Fan, R., Liu, B., Zhang, J. and Hu, D. (2009) Analysis of rDNA-ITS of Ustilaginoidea virens isolates from different geographical regions in China. Acta Phytophyl. Sin. 36, 475-476.

Yang, C., Li, L., Feng, A., Zhu, X. and Li, J. (2014) Transcriptional profiling of the responses to infection by the false smut fungus Ustilaginoidea virens in resistant and susceptible rice varieties. Can. J. Plant Pathol. 36, 377-388.

Yang, L., Chen, L., Xu, J., Liu, J. and Ding, K. (2012) Estimation of yield loss caused by rice false smut. J. Anhui Agric. Univ. 39, 474-477.

Yoshino, M. and Yamamoto, T. (1952) Pathogenicity of the chlamydospores of rice false smut. Agric. Hortic. Tokyo, 27, 291-292.

Yu, J.J., Sun, W.X., Yu, M.N., Yin, X.L., Meng, X.K., Zhao, J., Huang, L., Huang, L. and Liu, Y.F. (2015) Characterization of mating-type loci in rice false smut fungus Villosiclava virens. FEMS Microbiol. Lett. 362, fnv014.

Yu, M., Chen, Z., Hu, J., Yin, X., Nie, Y. and Liu, Y. (2013) Genetic diversity and pathogenicity of Ustilaginoidea virens isolated from different rice false smut balls of a diseased spike. Acta Phytophyl. Sin. 43, 561-573.

Yu, M., Yu, J., Gu, C., Nie, Y., Chen, Z., Yin, X. and Liu, Y. (2014) De novo sequencing and transcriptome analysis of Ustilaginoidea virens by using Illumina paired-end sequencing and development of simple sequence repeat markers. Gene, 547, 202-210.
Yu, M., Yu, J., Hu, J., Huang, L., Wang, Y., Yin, X., Nie, Y., Meng, X., Wang, W and Liu, Y. (2015) Identification of pathogenicity-related genes in the rice pathogen Ustilaginoidea virens through random insertional mutagenesis. Fungal Genet. Biol. 76, 10-19.

Zhang, T., Jiang, Y., Huang, J. and Dong, W. (2013a) Complete genome sequence of a putative novel victorivirus from Ustilaginoidea virens. Arch. Virol. 158, 1403-1406.

Zhang, T., Jiang, Y., Huang, J. and Dong, W. (2013b) Genomic organization of a novel partitivirus from the phytopathogenic fungus Ustilaginoidea virens. Arch. Virol. 158, 2415-2419.

Zhang, T., Jiang, Y. and Dong, W. (2014) A novel monopartite dsRNA virus isolated from the phytopathogenic fungus Ustilaginoidea virens and ancestrally related to a mitochondria-associated dsRNA in the green alga Bryopsis. Virology, 462-463, 227-235.

Zhang, Y., Zhang, K., Fang, A., Han, Y., Yang, J., Xue, M., Bao, J., Hu, D., Zhou, B., Sun, X., Li, S., Wen, M., Yao, N., Ma, L.J., Liu, Y., Zhang, M., Huang, F. Luo, C., Zhou, L., Li, J., Chen, Z., Miao, J., Wang, S., Lai, J., Xu, J.R., Hsiang, T., Peng, Y.L. and Sun, W. (2014) Specific adaptation of Ustilaginoidea virens in occupying host florets revealed by comparative and functional genomics. Nat. Commun. 5, 3849.

Zhang, Z., Du, X., Chai, R., Mao, X., Qiu, H., Wang, Y., Wang, J. and Sun, G. (2006) Agrobacterium tumefaciens-mediated transformation of the pathogen of Ustilaginoidea virens. Chin. J. Rice Sci. 20, 440-442.

Zhang, Z., Ye, S., Chai, R., Qiu, H., Wang, J. and Sun, G. (2010) Infection period and position of the fungus Ustilaginoidea virens based on the structure analysis of rice false smut balls. Acta Agric. Zhejiangensis, 22, 207-210.

Zheng, J., Zhang, Z., Jiang, H., Wang, Y., Chai, R., Qiu, H., Mao, X., Wang, J., Du, X., Lan, Z. and Sun, G. (2012) Establishment and preliminary application of a quantitative real-time PCR method for detection of conidia of Ustilaginoidea virens. Chin. J. Rice Sci. 26, 500-505.

Zhong, J., Lei, X.H., Zhu, J.Z., Song, G., Zhang, Y.D., Chen, Y. and Gao, B.D. (2014a) Detection and sequence analysis of two novel co-infecting double-strand RNA mycoviruses in Ustilaginoidea virens. Arch. Virol. 159, 3063-3070.

Zhong, J., Zhou, Q., Lei, X.H., Chen, D., Shang, H.H. and Zhu, H.J. (2014b) The nucleotide sequence and genome organization of two victoriviruses from the rice false smut fungus Ustilaginoidea virens. Virus Genes, 48, 570-573.

Zhong, J., Zhu, J.Z., Lei, X.H., Chen, D., Zhu, H.J. and Gao, B.D. (2014c) Complete genome sequence and organization of a novel virus from the rice false smut fungus Ustilaginoidea virens. Virus Genes, 48, 329-333.

Zhou, J. and Wang, X.-S. (2011) Field efficacy of $27.12 \%$ cuproxat SC against rice false smut Ustilaginoidea oryzae. Agrochem. Res. Appl. 15, 21-22.

Zhou, L., Lu, S., Shan, T., Wang, P., Sun, W., Chen, Z. and Wang, S. (2012) Chemistry and biology of mycotoxins from rice false smut pathogen. In: Mycotoxins: Properties, Applications and Hazards (Melborn, B.J. and Greene, J.C., eds), pp. 109-130. New York, NY: Nova Science Publishers.

Zhou, Y., Izumitsu, K., Sonoda, R., Nakazaki, T., Tanaka, E., Tsuda, M. and Tanaka, C. (2003) PCR-based specific detection of Ustilaginoidea virens and Ephelis japonica. J. Phytopathol. 151, 513-518.

Zhou, Y.-L., Xie, X.-W., Wang, S., Pan, Y.J., Liu, X.-Z., Yang, H., Xu, J.-L. and Li, Z.-K. (2006) Detection of Ustilaginoidea virens from rice field and plants by nested PCR. J. Agric. Biotechnol. 14, 542-545.

Zhou, Y.-L., Pan, Y.-J., Xie, X.-W., Zhu, L.-H., Xu, J.-L., Wang, S. and Li, Z.-K. (2008) Genetic diversity of rice false smut fungus, Ustilaginoidea virens and its pronounced differentiation of populations in North China. J. Phytopathol. 156, $559-564$.

Zhou, Y.-L., Xie, X.-W., Zhang, F., Wang, S., Liu, X.-Z., Zhu, L.-H., Xu, J.-L., Gao, Y.-M. and Li, Z.-K. (2014) Detection of quantitative resistance loci associated with resistance to rice false smut (Ustilaginoidea virens) using introgression lines. Plant Pathol. 63, 365-372.

Zhu, H.J., Chen, D., Zhong, J., Zhang, S.Y. and Gao, B.D. (2015) A novel mycovirus identified from the rice false smut fungus Ustilaginoidea virens. Virus Genes, 51, 159-162. 